\title{
Novel Concepts for the Application of Rapid DNA Technology as a Sentinel Event Prophylactic in the Criminal Justice System
}

\section{George W Adams*}

Member of the Texas Municipal Police Officers Association, USA

"Corresponding author: George W Adams, M.A, 2933 Oak Ridge Drive, Hurst, TX 76054, USA, Tel: (817) 657-4256; E-mail: gwa337687@iCloud.com

Rec date: Dec 29, 2014, Acc date: March 20, 2015, Pub date: March 27, 2015

Copyright: ( 2015 Adams GW. This is an open-access article distributed under the terms of the Creative Commons Attribution License, which permits unrestricted use, distribution, and reproduction in any medium, provided the original author and source are credited.

\begin{abstract}
Rapid DNA Technology (RDNA) holds the key to the elimination of a significant number of sentinel events. Sentinel events in the criminal justice system may best be explained through the Joint Commission on Accreditation of Health Care Organizations' (JACHO) definition as "an unexpected occurrence involving death or severe physical or psychological injury, or the risk thereof". The most notable sentinel event in the criminal justice system today is a wrongful conviction - which exposes all attendant parties to significant personal and institutional liabilities. The International Association of Chiefs of Police/U.S. Department of Justice released its August report on the Wrongful Convictions Summit. In the report, there were thirty recommendations to reduce sentinel events in the criminal justice system. Sentinel events are likely the result of compound errors. The recommendations of the Summit Advisory Group focused on preventing the compounding of errors (racial profiling, investigative biases, aggressive interviewing, faulty line-up protocols, false testimony and eyewitness errors) to which Doyle refers. Currently, the public safety community seems to be virtually silent on the use of RDNA as a sentinel event prophylactic in fulfilling the criminal justice system's goal to protect the blameless while holding the blameworthy accountable. The injection of RDNA at the earliest opportunity in the pre-charging phase of the criminal process may provide relief from the seemingly endless rise of sentinel events in the criminal justice system.
\end{abstract}

Keywords: Rapid DNA technology; Sentinel events; Criminal justice; Psychological injury; Forensics

\section{Concepts}

The purpose of this manuscript is to explore the application of rapid DNA technology (RDNA) as a prophylactic for the elimination of a significant number of sentinel event factors in the pursuit of truth and justice. A "sentinel event" is a bad outcome that no one wants repeated and that signals the existence of underlying weaknesses in the criminal justice system. "Sentinels stand watch," says James Doyle. "They detect the first signs of a looming threat and sound a warning that should not be ignored" [1-4]. "I have never heard a sound beating in the air, So fraught with the spirit of trouble and need of assistance, As the sharp crack of the watchman's rattle Reverberating in the street at the dead hour of night", as said by Edward H. Savage [5]. NIJ's Sentinel Event Initiative, for the criminal justice system, borrows from health care and aviation industries a forward looking and non-blaming approach for problem-solving [6]. In that regard certain key concepts are critical to understand.

In the health care industry, a sentinel event is defined as a serious adverse outcome involving death, serious physical or psychological injury, or the "risk thereof". The event is referred to as "sentinel" as there is a need for immediate response and action often referred to as a root cause analysis (RCA) [1]. Sentinel events encompass "near misses" in the criminal justice system - in which tragic outcomes are eventually averted $[1,6]$. "Near misses" may be equated with the expression "risk thereof" in the health care industry. In addition to sentinel events and near misses, the health industry brings forward the term "never events" that is also relevant to the criminal justice system. "Never events" is the colloquial term applied to serious, preventable, and costly errors in the provision of health care services...that should "never" occur [7]. Sentinel events in the health care industry involve situations that are serious in nature, tragic outcomes that should never happen (never events) and high risk circumstances (near misses) that could have easily resulted in harm to patient. A root cause analysis, which is immediately undertaken while all evidence is available and recoverable, functions to mitigate subjective interpretations in both health care and aviation industries. In the criminal justice system an immediate root cause analysis may not be possible. Sentinel events may not become known until years or decades after its initial occurrence when necessary evidence and witnesses to the initial occurrence is no longer available or recoverable.

Sentinel events in the aviation industry focuses on "human factors" which may be referred to as errors and violations. The terms are different from the health care industry; however, the concept and outcomes are the same. Errors represent the mental or physical activities of individuals that fail to achieve their intended outcome. Not surprising, given the fact that human beings by their very nature make errors, these unsafe acts dominate most accident databases. Violations on the other hand, are much less common and refer to the wilful disregard for the rules and regulations that govern the safety of flight [8]. The truth is that we are all human beings. As such, errors, violations, biases, complacency and an inexhaustible number of other human factors will be part of this concept, we call the human experience. Rapid DNA technology offers the potential to provide a shield (prophylactic) from an inexhaustible number of human factors contributing to the significant and diverse amount of sentinel events plaguing the criminal justice system. RDNA may be conceptualized as a lab in a box. Currently there are two major types of RDNA equipment: General Electric - DNAscan and IntegenX - RapidHit 200. RDNA provides the ability for agencies to produce usable results 
in under ninety-minutes or collection to result in less than two hours. RDNA has the potential to provide near real time access go DNA typing expertise via automation.

\section{Historical Perspective}

"In the pursuit of truth and justice we need to keep in mind one of Tolstoy's passion for truth: Truth, like gold, is to be obtained not by its growth, but by washing away from it all that is not gold" as quoted by Lev Nikolayevich Tolstoy (1828-1910).

The awareness of aviation's human factors contributions to one of the industry's first sentinel events probably began with the September 17, 1908 fatality crash of the Army's first airplane resulted death of Lt. Thomas Selfridge, and serious injury to Orville Wright. The Board of Inquiry brought attention to the need for crew and passengers to wear seatbelts and helmets. Medical examines increased participation in aircraft investigation to determine the extent for which human factors contributed to the fatal crashes. A multitude of factors were identified; intervention efforts appear to have failed. For twelve months ending October 31, 1965 there was 122 fatal general aviation accidents with 206 fatalities. "Of particular concern was the frequency with which family, friends, and local officials knew the habits and physical and mental conditions of the pilots and tolerated the situation [9].

Humans, by their very nature, make mistakes; therefore, it should come as no surprise that human error has been implicated in a variety of occupational accidents, including $70 \%$ to $80 \%$ of those in civil and military aviation [8]. Clearly, if accidents are to be reduced further, more emphasis must be placed on the genesis of human error as it relates to accident causation [8].

In a 2013 report in the Journal of Patient Safety, cites numbers of the Institute of Medicine which estimates that 1984 data developed from reviews of New York hospitals that up to 98,000 die each year from medical errors. The true number of premature deaths associated with preventable harm to patients was [now] estimated at more than 400,000 per year [10]. In the Joint Commission on Accreditation of Healthcare Organizations' January sentinel event alert, it was reported that according to estimates from the Centers for Disease Control and Prevention (CDC), each year nearly two million patients in the United States get an infection in hospitals, and about 90,000 of these patients die as a result of their infection [11]. Regardless of the true numbers of sentinel events occurring in the health care industry happen to be, one thing appears to abundantly clear, current methods of dealing individually with the various types sentinel events is very difficult with which to deal. The aviation industry seems to reflect the same experience. The criminal justice shares the same experience, with the exception that criminal justice system sentinel events are not known until years after the event actually occurred.

\section{Contemporary Perspective}

According to the National Institute of Justice, a sentinel event is a significant negative outcome that: signals underlying weaknesses in the system or process; is likely the result of compound errors; may provide, if properly analyzed and addressed, important keys to strengthening the system and preventing future adverse events or outcomes. A few examples of sentinel event factors in the criminal justice system of the United States may be highlighted by the following:
- Wrongful conviction or near-miss when an individual is accused of a criminal act

- Labelling of an individual when questioned by investigators relative a criminal case

- Inaccurate eye-witnesses testimony

- False statements from informants, victims or witnesses

- Over-reaching forensic subject matter expert testimony

- Exoneration outcomes: liability risk for criminal justice personnel and agencies

Mounting evidence for the necessity for a prophylactic application to eliminate a significant number of sentinel event factors is demonstrated by the following:

- 20-25\% of Innocence Project cases successfully litigated included false confessions [12]

- National Registry of Exonerations shows 1,450 exonerations as of October 19, $2014[13,14]$.

- Case exemplar: "Beatrice Six" defendants who confessed to murder in 1989 were exonerated when DNA evidence identified another suspect not associated with defendants - a 42 USC Sec. 1983 claim filed against investigating parties [15].

\section{Conclusions}

As investigators go about their search for justice, they seek probable cause as part of the investigative due diligence to establish grounds to charge an offender. Due diligence requires that investigators, investigate all leads to confirm probable cause for moving forward with investigating the lead or to refute that particular investigative lead. Circumstances, witnesses or opinions of forensic subject matter experts may provide an investigator reasonable suspension that an individual may be a viable person of interest (suspect). Reasonable suspension "may be used to establish probable cause to obtain an evidentiary DNA sample from the suspect. The law enforcement agency can use this documentation to obtain a court order authorizing the collection of a known biological reference sample from the offended [16]. In law enforcement, probable cause is a reasonable suspension by a prudent officer that an offense has been committed or may soon be committed. Likewise, investigators may us the lack of probable cause to end additional investigation efforts in followingupon that particular line of inquiry. The problem for investigators is how to definitively document their decision to end that line of inquiry. It is of special concern to investigators to be able to have physical, objective documentation to support their decisions in defence of their actions available years and decades after the fact in wrongful conviction claims by innocent defendants - due to the subjective interoperations of the investigative actions.

The solution is surprisingly simple. Once DNA evidence is obtained from a crime scene, the person of interest may be asked to voluntarily provide a simple buccal swab for RDNA analysis. In less than two hours, the DNA profile may be obtained and the person of interest may be eliminated or may be found to be a possible match to the forensic DNA profile from the crime scene, in accordance with established agency protocols. The DNA results may be transmitted electronically to a subject matter expert for consultation of almost immediately.

"The match of the forensic DNA record against the DNA record in the database may be used to establish probable cause to obtain an evidentiary DNA sample from the suspect. The law enforcement 
Citation: Adams GW (2015) Novel Concepts for the Application of Rapid DNA Technology as a Sentinel Event Prophylactic in the Criminal Justice System. J Forensic Res 6: 1000278. doi:10.4172/2157-7145.1000278

Page 3 of 4

agency can use this documentation to obtain a court order authorizing the collection of a known biological reference sample from the offender" $[16,17]$.

Whether RDNA provides elimination or match, the impact on the investigator and person of interest is brought to a rapid decision necessary in the pursuit of justice for both victim and accused. As in the healthcare and aviation industries, proactive intervention is less expensive and more efficacious than corrections after the fact. Unfortunately in the criminal justice system, sentinel events may occur and re-occur for years and decades in other cases until discovered. Should RDNA be injected in to investigative protocols many sentinel event factor are muted - never to have an opportunity to come into existence (Figure 1).

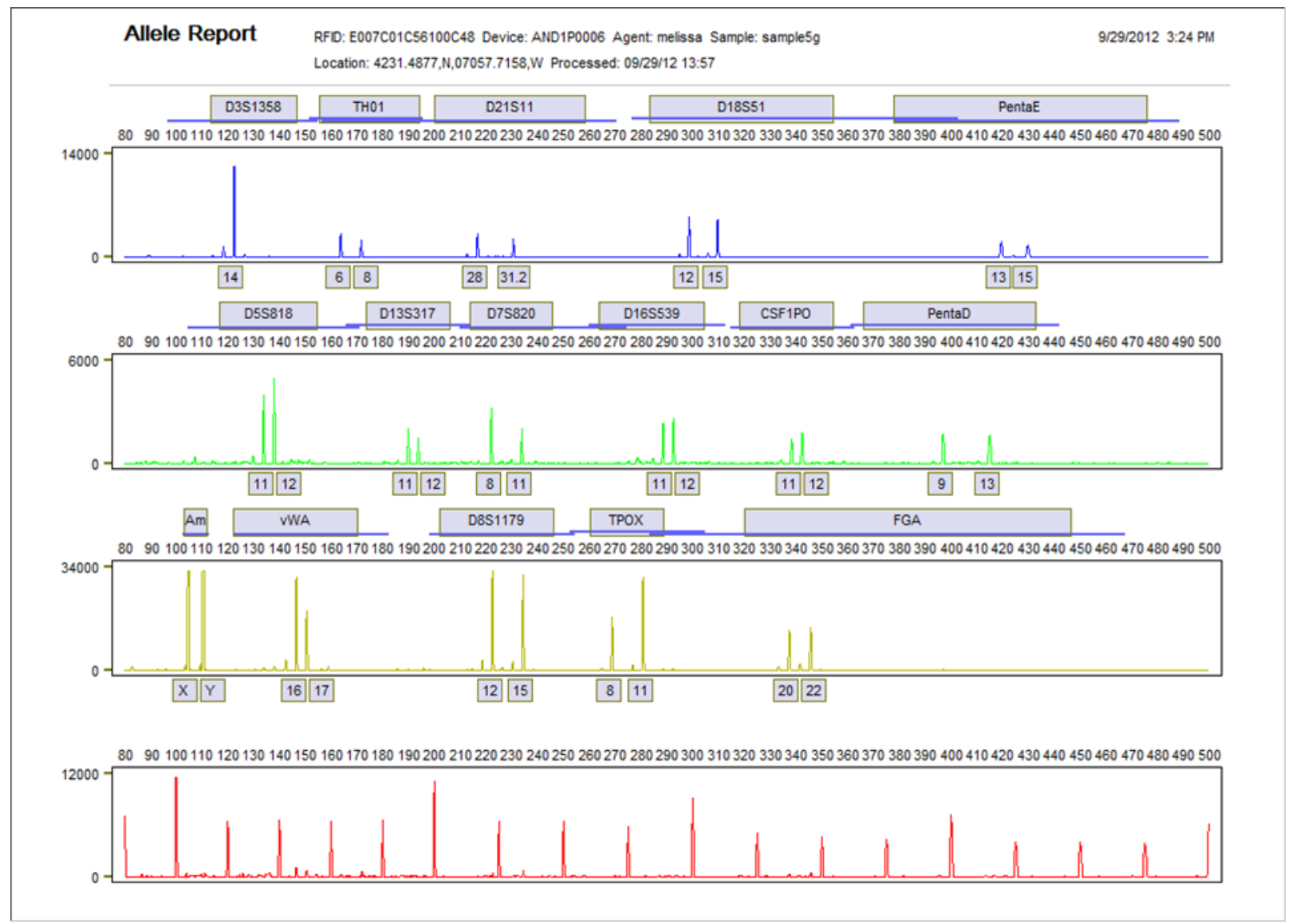

Figure 1: Allele report utilizing DNAscan, general electric healthcare - Courtesy of the author George W. Adams

\section{References}

1. Joint Commission (2014) Sentinel Event.

2. International Association of Chiefs of Police Department of Justice Office Of Justice Programs (2013) National summit on wrongful convictions: Building a systematic approach to prevent wrongful convictions. Summit 1: $18-20$.

3. Doyle JM (2013) NIJ's sentinel events inigtiative: Looking back to look forward. NIJ Journal, 273 (NCJ 244145), 11-14.

4. National Institute Of Justice (2014) Mending justice: Sential event reviews (NCJ 247141). Washington, DC: U.S. Government Printing Office.

5. Costa RD, Wilson EO (2010) watchman's rattle: Thinking our way out of extinction New York, NY: Vanguard Press.

6. Office of Justice Programs National Institute of Justice (2014) NIJ's sentinel events initiative.

7. American Health Lawyers Association, (2010, July).

8. Shappell SA, Wiegmann DA (2003) Human error and general aviation accidents: A comprehensive, fine-grained analysis using hfacs.
9. Dille JR, Morris EW (1966) Human factors in general aviation accidents. Dille, (AM - 66-27). Springfield, VA: Clearinghouse for Federal Scientific and Technical Information.

10. James JT (2013) New, evidence-based estimate of patient harms associated with hospital care. Journal of Patient Safety, 9: 122-128.

11. Joint Commission (2003) Sentinel event alert; Infection control related sentinel events 28 .

12. Jenson JK (2014) delima and debate over confession evidence strategies. Journal of Forensic Research criminal studies 1: 1-10.

13. University Of Michigan Law School Center On Wrongful Convictions At Northwestern University School Of Law (2014) national registry of exonerations

14. US Department of Justice Office of Justice Programs National Institute of Justice (2014) Research on "sentinel events" and criminal justice system errors.

15. Sheppard Circuit Judge (2012) Thomas W. Wilson v Richard T. Smith Sheppard, No. 11-2884. 
Citation: Adams GW (2015) Novel Concepts for the Application of Rapid DNA Technology as a Sentinel Event Prophylactic in the Criminal Justice System. J Forensic Res 6: 1000278. doi:10.4172/2157-7145.1000278

Page 4 of 4

16. The FBI Federal Bureau of Investigation. n/d. Laboratory Services: Frequently Asked Questions (FAQs) on the CODIS Program and the National DNA Index System.

17. Wiegmann DA, Shappell SA (2001) human error analysis of commercial aviation accidents using the human factors analysis and classification system (HFACS) (DOT/FAA/AM-01/3). Springfield, VA: National Technical Information Service. 